\title{
Determination of Amitriptyline and its Main Metabolites in Human Plasma Samples using HPLC-DAD: Application to the Determination of Metabolic Ratios after Single Oral Dose of Amitriptyline
}

\author{
Rafael Linden, ${ }^{*, a}$ Marina Venzon Antunes, ${ }^{a}$ Ana Luiza Ziulkoski, ${ }^{a}$ Maína Wingert, ${ }^{a}$ \\ Paula Tonello, ${ }^{a}$ Mladen Tzvetkov ${ }^{b}$ and André Arigony Souto ${ }^{c}$
}

\author{
${ }^{a}$ Centro Universitário Feevale, Rodovia RS 239, 2755, 93352-000 Novo Hamburgo-RS, Brazil \\ ${ }^{b}$ Department of Clinical Pharmacology, Georg-August-Universität Göettingen, \\ Robert-Koch Str. 40, 37075, Göettingen, Germany \\ 'Pontifícia Universidade Católica do Rio Grande do Sul, Av. Ipiranga, 6681, \\ 90619-900 Porto Alegre-RS, Brazil
}

\begin{abstract}
Foi desenvolvido e validado um método simples e rápido, empregando CLAE-DAD, para a determinação simultânea de amitriptilina, nortriptilina, E-10-hidroxiamitriptilina, Z-10hidroxiamitriptilina, E-10-hidroxinortriptilina, Z-10-hidroxinortriptilina e desmetilnortriptilina em amostras de plasma humano. O método utiliza extração líquido-líquido em duas etapas e separação isocrática em fase reversa. A precisão apresentou D.P.R. \% menor que $12.1 \%$ e a precisão esteve na faixa entre 93,1 e $102,5 \%$. O limite de detecção foi $5 \mathrm{ng} \mathrm{mL}^{-1}$ para todos os analitos. Foram avaliadas razões metabólicas de desmetilação da amitriptilina em indivíduos genotipados para CYP2C19, com nítidas diferenças entre os valores obtidos nos voluntários com zero ou dois alelos ativos. O método é adequado para o monitoramento terapêutico de pacientes em terapia com amitriptilina, permitindo também a indicação da atividade de CYP2C19.
\end{abstract}

A simple and sensitive HPLC-DAD method for the simultaneous determination of amitriptyline, nortriptyline, E-10-hydroxyamitriptyline, Z-10-hydroxyamitriptyline, E-10-hydroxynortriptyline, Z-10-hydroxynortriptyline and desmethylnortriptyline in human plasma samples was developed and validated. The method employs a two step liquid-liquid extraction and a reversed phase separation with isocratic elution. Precision assays showed R.S.D \% lower than $12.1 \%$ and accuracy was in the range of 93.1 to $102.5 \%$. Lowest Limit of detection was $5 \mathrm{ng} \mathrm{mL}^{-1}$ for all analytes. Metabolic ratios of amitriptyline demethylation were evaluated in individuals genotyped for CYP2C19, with clear differences between volunteers with zero or two active alleles. The method is suitable for therapeutic drug monitoring of patients under amitriptyline treatment, also allowing the indication of CYP2C19 activity.

Keywords: amitriptyline, HPLC-DAD, CYP2C19, metabolic ratios

\section{Introduction}

Amitriptyline (AT), even after 40 years of its introduction still is a leading drug in the treatment of depression, specially in developing countries. ${ }^{1,2}$ AT is metabolized mainly by demethylation forming nortriptyline (NT) (Figure 1), and by hydroxylation, leading to the formation of E-10-hydroxy (EHAT) and Z-10hydroxyamitriptyline (ZHAT). NT is further demethylated

*e-mail: rafael.linden@ feevale.br to desmethylnortriptyline (NNT) and hydroxylated to E-10hydroxy (EHNT) and Z-10-hydroxynortriptyline (ZHNT). The demethylation of AT and NT is mainly catalyzed by CYP2C19, with the participation of other CYP enzyme forms in higher drug concentrations. ${ }^{3}$ The formation of the E-10-hydroxy metabolites is dependent on the activity of CYP2D6, with stereospecificity to the (-)-EHAT and (-)-EHNT metabolites. ${ }^{3}$

Therapeutic drug monitoring (TDM) in AT pharmacotherapy is usually based on the determination of plasma concentrations of AT and its main active 
metabolite, NT, once better clinical outcome in the treatment of depression is expected with plasma steady state concentrations of AT $+\mathrm{NT}$ in the range of 80 to $200 \mathrm{ng} \mathrm{mL}^{-1}$, with an increased incidence of adverse effects when plasma levels are above $300 \mathrm{ng} \mathrm{mL}^{-1} .4,5$ Additional information can be obtained through the determination of the hydroxylated metabolites of AT and NT, once these metabolites are correlated with important clinical findings. A trend to better clinical outcome in the treatment of depression was observed with higher EHAT and EHNT plasma concentrations, ${ }^{6}$ and some earlier reports associated the occurrence of severe cardiovascular toxicity to high plasma levels of EHNT and ZHNT after intake of therapeutic doses of NT. ${ }^{7-10}$ Recently, some authors proposed AT individualized dose adjustments based on genotype-predicted phenotype of CYP2D6 and CYP2C19. ${ }^{11}$ Another approach, to be investigated in this work, is the evaluation of the activity of CYP2C19 in AT pharmacotherapy through the determination of metabolic ratios for demethylation of AT after a single oral dose, as has been done with phenotyping probes as omeprazole. ${ }^{12}$

Several analytical methods have been developed for the determination of AT and some of its metabolites in human plasma using either gas, ${ }^{13,14}$ or liquid chromatography. ${ }^{15,16}$ To the best of our knowledge, there is only one report on simultaneous determination of AT, NT, NNT, EHAT,
ZHAT, EHNT and ZHNT in biological samples, which was done by LC-MS/MS. ${ }^{17}$ Therefore, there is no report of a low-cost HPLC-UV method to simultaneously determine AT and its 6 main metabolites. Additionally, the use of a diode array detector (DAD) detector coupled to the HPLC system permits the use of comprehensive databases of UVspectra for DAD, allowing a reliable identification of the analytes and of unknown compounds eventually present on the sample. ${ }^{18}$

In this manuscript, we describe a simple and fast HPLCDAD method for simultaneous determination of AT and its demethylated and hydroxylated metabolites in small samples of human plasma. The method was applied to a pilot study in the determination of demethylation metabolic ratios of AT after a single oral dose in individuals previously genotyped for CYP2C19.

\section{Experimental}

\section{Chemicals}

Amitriptyline (99\%), nortriptyline (99\%) and clomipramine $(99 \%)$ hydrochlorides were obtained from Purifarma Química e Farmacêutica (São Paulo, Brazil). E-10-hydroxyamitriptyline (EHAT) (98\%),

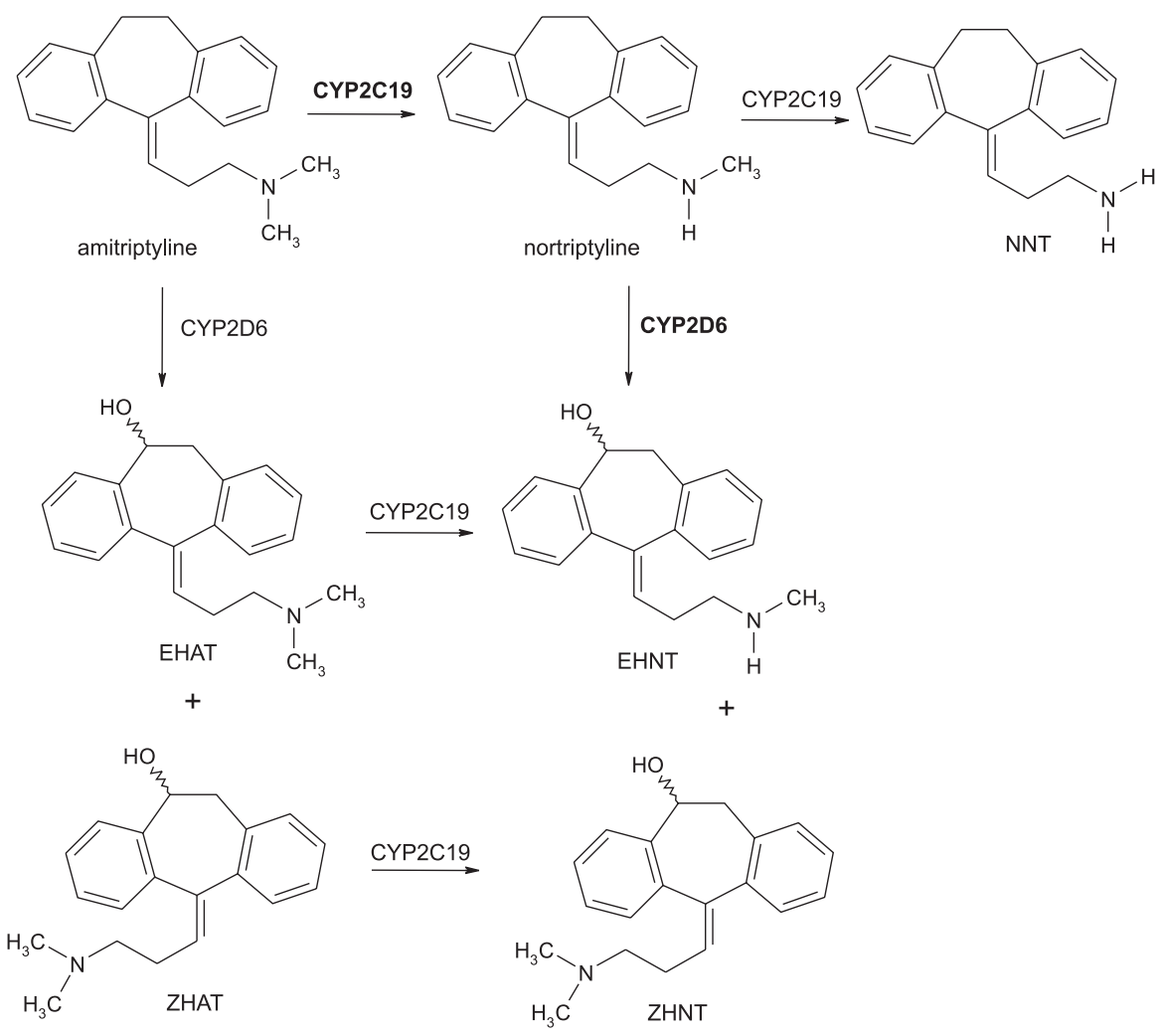

Figure 1. Main metabolic pathways of amitriptyline. Major routes are shown in bold. 
Z-10-hydroxyamitriptyline (ZHAT) (99\%), E-10hydroxynortriptyline (EHNT) (99\%), Z-10-hydroxynortriptyline (ZHNT) (98\%) and desmethylnortriptyline (NNT) (97\%) were kindly donated by Lundbeck A/S (Copenhagen, Denmark). HPLC grade acetonitrile, isopropylic alcohol, monobasic sodium phosphate, anhydrous dibasic sodium phosphate, hydrochloric and phosphoric acids were obtained from Merck (Darmstadt, Germany). HPLC grade $n$-hexane was obtained from Malinkrodt (Philisburg, USA). Ultrapure water was obtained by means of an Elga Purelab Ultra SC apparatus from Elga Labwater (High Wycombe, UK). Generic amitriptyline 25 mg tablets were manufactured by Eurofarma Laboratórios Ltda (São Paulo, Brazil).

\section{Equipment}

The chromatographic apparatus consisted of a binary pump LC-10AT, an on line degasser DGU-14, a column oven CTO 10AS, an automatic injector SIL-10AF and a diode array detector SPDM10A. The system was controlled by the software Class VP 6.13 SP2. The complete system was obtained from Shimadzu (Kyoto, Japan).

\section{Chromatographic conditions}

The separation was performed on a Lichrospher RP8ec ( 250 x $4.0 \mathrm{~mm}$ i.d., $5 \mu \mathrm{m}$ ) column with a guard column Lichrospher RP8e $(10 \times 4.0 \mathrm{~mm}$ i.d., $5 \mu \mathrm{m})$, both from Merck (Darmstadt, Germany). The integration wavelength was set at $210 \mathrm{~nm}$, with diode array spectral acquisition in the range of 200 to $380 \mathrm{~nm}$. The mobile phase consisted of phosphate buffer $\mathrm{pH} 2.3$ and acetonitrile $(63: 37, \mathrm{v} / \mathrm{v})$ at

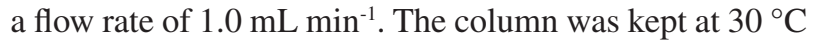
during the analyses. The autosampler was maintained at room temperature.

\section{Standard solutions}

Stock solutions of the analytes were prepared in methanol at the concentration of $100 \mu \mathrm{g} \mathrm{mL}^{-1}$, calculated as base. The stock solution of clomipramine (internal standard) was prepared in methanol at a concentration of $100 \mu \mathrm{g} \mathrm{mL}^{-1}$. Stock solutions were stable for at least two months, when stored at $-20^{\circ} \mathrm{C}$. Working solutions were prepared daily from stock solutions by dilution with methanol.

\section{Biological samples}

Pooled blank plasma used to obtain the calibration samples was obtained from healthy volunteers. EDTA blood samples $(5 \mathrm{~mL})$ were collected for genotyping and pharmacokinetic analysis. All samples were stored at $-20{ }^{\circ} \mathrm{C}$, being thawed just before use.

\section{Sample preparation}

To $500 \mu \mathrm{L}$ of plasma in a glass-stoppered $10 \mathrm{~mL}$ centrifuge tube, $50 \mu \mathrm{L}$ of internal standard working solution $\left(2 \mu \mathrm{g} \mathrm{mL} \mathrm{m}^{-1}\right), 500 \mu \mathrm{L}$ of Tris buffer $\mathrm{pH} 9.5$ and $5 \mathrm{~mL}$ of hexane: isopropylic alcohol $(95: 5, \mathrm{v} / \mathrm{v})$ were added. After vortex mixing $(1 \mathrm{~min})$, the mixture was centrifuged at $3500 \mathrm{~g}$ for $10 \mathrm{~min}$ and the organic phase was transferred to another glass stoppered tube to which $150 \mu \mathrm{L}$ of phosphoric acid $0.1 \%(\mathrm{v} / \mathrm{v})$ was previously added. This mixture was vortex mixed for $1 \mathrm{~min}$ and then centrifuged at $3500 \mathrm{~g}$ for $10 \mathrm{~min}$. The organic layer was discharged and $100 \mu \mathrm{L}$ of the aqueous phase were transferred for a microvial for autosampler and $50 \mu \mathrm{L}$ were injected.

\section{Genotyping}

The CYP2C19 genotyping assay was carried out using a Real-Time-PCR-based assay, (TaqMan ${ }^{\circledR}$ Assay \# C__1329163_10, Applied Biosystems), following the manufacturer's instructions. The genotyping procedure screened for the CYP2C19*1, *2 and *3 alleles.

\section{Plasma calibration curves and Lower Limit of Quantitation}

To $450 \mu \mathrm{L}$ of blank plasma, $50 \mu \mathrm{L}$ of the working standards containing all analytes were added, yielding final concentrations of AT, NT, NNT, EHAT, ZHAT, EHNT and ZHNT in the range of 5 to $500 \mathrm{ng} \mathrm{mL}^{-1}$. To this mixture, $50 \mu \mathrm{L}$ of internal standard working solution were added to yield a IS concentration of $200 \mathrm{ng} \mathrm{mL}^{-1}$. Each calibration level was analyzed in sextuplicate. Calibration curves were constructed by means of the least-squares method, with a weighting factor of concentration ${ }^{-2}$. The regression was evaluated for goodness-of-fit and lack-of-fit, with a confidence level of 5\%. The Lower Limit of Quantitation (LLOQ) was established as the lowest concentration evaluated yielding acceptable precision (R.S.D. < $20 \%$ ) and accuracy (80-120\% of theoretical value), according do Shah et al. ${ }^{19}$

\section{Selectivity, precision and accuracy}

Control human blank plasma, obtained from 10 healthy volunteers, was assessed by the procedure described above to evaluate for the presence of inferring endogenous peaks. 
In all runs, peaks related to AT, NT, NNT, EHAT, ZHAT, EHNT and ZHNT were evaluated with respect to their spectral purity and compared with reference spectra at DAD library. Precision and accuracy were examined by adding known amounts of analytes to blank plasma, yielding final concentrations of 15, 200 and $400 \mathrm{ng} \mathrm{mL}^{-1}$ of each analyte. Quality control samples were analyzed in triplicate on each of 6 days. The 18 measured concentrations per concentration level were subjected to analysis of variance (ANOVA), considering day as the grouping variable. Precision was expressed as percentage relative standard deviation (R.S.D. $\%$ ). Accuracy was calculated by comparing the mean of the 18 measured concentrations per concentration level with the nominal concentration and expressed as percentage of the spiked concentration.

\section{Extraction yield}

The absolute recovery was determined at three different concentrations of analytes $\left(15,200\right.$ and $\left.400 \mathrm{ng} \mathrm{mL}^{-1}\right)$. The plasma samples were analysed as in the sample preparation section. The absolute recovery was calculated by comparing the peak areas for extracted analytes from spiked plasma and a standard solution of the compounds in methanol containing internal standard with the same initial concentration (six samples for each concentration level).

\section{Pharmacokinetic study design and sample collection}

The pharmacokinetic pilot study protocol was approved by the Ethics Committees of Centro Universitário Feevale, and a written informed consent was obtained from the volunteers. The volunteers were previously genotyped for CYP2C19, according to the Genotyping section. Subjects were excluded of the study if they had any factor affecting AT pharmacokinetics or had a reported allergy to drugs. AT was administered in a single oral dose of $1 \mathrm{mg} \mathrm{kg}^{-1}$ body mass to the volunteers after a 8 hours fasting. Blood samples were collected pre-dose and at 1, 2, 3, 4, 5 and 7 hours after dosing. After collection, plasma was immediately separated, transferred to polypropylene tubes and frozen at $-20{ }^{\circ} \mathrm{C}$ until assayed. Demethylation metabolic ratio was calculated as $[\mathrm{AT}] /[\mathrm{NT}]$.

\section{Results and Discussion}

\section{Chromatographic conditions}

Under the chromatographic conditions described, AT, NT, NNT, EHAT, ZHAT, EHNT and ZHNT and the internal standard peaks were well resolved, without endogenous interfering peaks. Complete separation was achieved in less than $23 \mathrm{~min}$. Fortunately, the chosen chromatographic conditions allowed the use of a comprehensive database of relative retention times and DAD spectra, acquired between 200 and $380 \mathrm{~nm}$, as proposed by Pragst et al. ${ }^{21}$ Fortunately, the combination of acidic mobile phase and fully endcapped reversed phase column provided adequate resolution and peak shapes, making the use of amine modifier unnecessary. The average retention times EHNT, EHAT, ZHNT, ZHAT, NNT, NT, AT and internal standard were 3.7, $4.1,4.5,5.1,10.8,13.4,15.2$ and $21.9 \mathrm{~min}$, respectively (Figure 2).
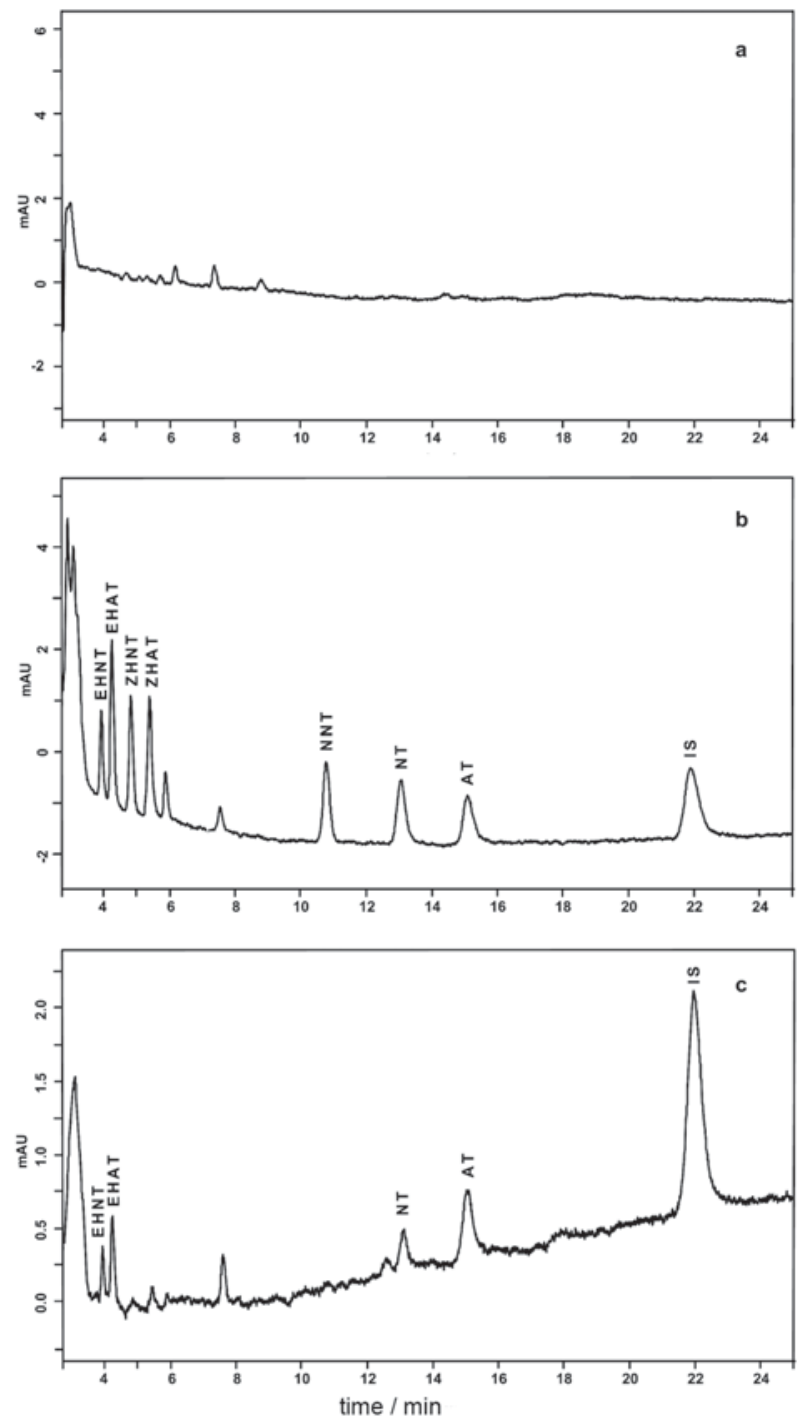

Figure 2. Chromatograms of: (a) blank plasma sample; (b) blank plasma sample spiked with $50 \mathrm{ng} \mathrm{mL}^{-1}$ of EHNT, EHAT, ZHNT, ZHAT, NNT, NT and AT, and $200 \mathrm{ng} \mathrm{mL}^{-1}$ of IS; and (c) plasma sample of a volunteer three hours after an oral intake of $1 \mathrm{mg} \mathrm{kg}^{-1}$ AT. Concentrations in (c) are: EHNT $14.1 \mathrm{ng} \mathrm{mL}{ }^{-1}$, EHAT $16.7 \mathrm{ng} \mathrm{mL}^{-1}$, NT $18.9 \mathrm{ng} \mathrm{mL}^{-1}$ and AT $46.1 \mathrm{ng} \mathrm{mL}^{-1}$. 


\section{Sample preparation}

Plasma and blood samples has been extracted for the determination of AT and metabolites mainly by solid-phase and liquid-liquid extraction procedures. The latter option, besides its favorable cost characteristics, can provide very clean extracts when submitted to a subsequent backextraction to an acidic aqueous solution. The cleanness of these extracts allows the use of shorter wavelengths for analyte quantification, increasing sensitivity. Differently from other studies, we used small volumes of sample, allowing reanalysis if needed, even with typical amounts of collected plasma. The smallest extraction yield was obtained with EHNT (37.4\%). All the other compounds presented recoveries above $70 \%$, with maximum recovery of $83.7 \%$ for ZHAT (Table 2). Considering the lack of endogenous chromatographic interference with this two step liquid-liquid extraction, even the compounds with smaller yields presented adequate limits of detection. In addition, the fast preparation of samples due to the absence of a solvent evaporation step represents a considerable advantage. The whole sample preparation process does not take more than 25 minutes.

\section{Validation method}

Once area ratios of analytes to internal standard presented significant heteroscedasticity through the range of concentration of the calibration curve, weighted linear regression was used to fit the data, with a weighting factor of concentration ${ }^{-2}$. Acceptable linearity's were obtained for all analytes, with values of $\mathrm{r}^{2}$ between 0.992 for EHAT and 1.000 for NNT. The goodness of fit was highly significant and no significant lack-of-fit was observed in any of the calibration curves (Table 1). The LLOQ for all compounds evaluated was $5 \mathrm{ng} \mathrm{mL}^{-1}$. Precision results were also satisfactory, with R.S.D. \% values for intra-assay precision always lower than or equal to $10.5 \%$, and R.S.D. \% values for inter-assay precision lower than or equal to $12.1 \%$. Accuracy was also acceptable, ranging from 93.1 to $102.5 \%$. Complete precision, extraction yield and accuracy data are presented at Table 1 . No interfering peaks were identified in blank samples. In all analysis, peaks were evaluated with respect to spectral purity by the DAD and we did not found any impurity at the peaks related to AT, NT, NNT, EHAT, ZHAT, EHNT and ZHNT and internal standard.

A group of five Brazilian volunteers received a single oral dose of $1 \mathrm{mg} \mathrm{kg}^{-1}$ AT. In this group, 4 individuals presented two CYP2C19 active alleles and one individual presented no active alleles. The maximal observed concentrations of AT, NT, EHAT, EHNT and ZHNT were $162.8,32.4,17.2,65.4$ and $43.0 \mathrm{ng} \mathrm{mL}^{-1}$, respectivelly. Maximum detected ZHAT concentrations were below the LLOQ and were not quantified in any sample. Metabolic ratios for demethylation were calculated at the times where maximal AT and NT were achieved (Table 3). At 3 hours after drug administration, the volunteer without $C Y P 2 C 19$ active alleles presented AT demethylation ratio ([AT]/[NT]) 10.6 times higher than the average of volunteers with two active alleles.

Our study shows that it is feasible to detect unusual activity of CYP2C19, at the start of the pharmacotherapy with AT, without the use of probe drugs or genotyping procedures. To achieve this purpose, a blood sample can be drawn 3 hours after oral AT intake and the demethylation ratio can be determined, with a simple and fast HPLC method.

Table 1. Assay linearity and regression analysis*

\begin{tabular}{|c|c|c|c|c|c|c|c|c|}
\hline \multirow[t]{2}{*}{ Substance } & \multirow[t]{2}{*}{ Parameter } & \multirow[t]{2}{*}{ Coefficient } & \multirow[t]{2}{*}{ Standard error } & \multirow[t]{2}{*}{$\mathrm{r}^{2}$} & \multicolumn{2}{|c|}{$F$-test for goodness of fit } & \multicolumn{2}{|c|}{$F$-test for lack-of-fit } \\
\hline & & & & & $\mathrm{F}$ & p-value & $\mathrm{F}$ & $\mathrm{p}$-value \\
\hline \multirow[t]{2}{*}{$\overline{\mathrm{AT}}$} & Slope & 0.009 & 0.006 & 0.994 & 2722.45 & $0.0001 * *$ & 0.0492 & $0.9951 * * *$ \\
\hline & Intercept & 0.018 & 0.001 & & & & & \\
\hline \multirow[t]{2}{*}{ NT } & Slope & 0.010 & 0.000 & 0.998 & 3562.9 & $0.0001 * *$ & 0.0252 & $0.9987 * * *$ \\
\hline & Intercept & -0.001 & 0.004 & & & & & \\
\hline \multirow[t]{2}{*}{ NNT } & Slope & 0.010 & 0.001 & 1.000 & 9188.2 & $0.0001 * *$ & 0.2604 & $0.9004 * * *$ \\
\hline & Intercept & -0.002 & 0.000 & & & & & \\
\hline \multirow[t]{2}{*}{ ZHAT } & Slope & 0.008 & 0.001 & 0.992 & 3201.3 & $0.0001 * *$ & 0.0514 & $0.9517 * * *$ \\
\hline & Intercept & 0.019 & 0.006 & & & & & \\
\hline \multirow[t]{2}{*}{ EHAT } & Slope & 0.009 & 0.001 & 0.993 & 2998.7 & $0.0001 * *$ & 0.0487 & $0.9814 * * *$ \\
\hline & Intercept & 0.070 & 0.006 & & & & & \\
\hline \multirow[t]{2}{*}{ ZHNT } & Slope & 0.004 & 0.000 & 0.994 & 3114.8 & $0.0001 * *$ & 0.6297 & 0.9752 *** \\
\hline & Intercept & 0.020 & 0.002 & & & & & \\
\hline \multirow[t]{2}{*}{ EHNT } & Slope & 0.006 & 0.000 & 0.993 & 2685.1 & $0.0001 * *$ & 0.0341 & $0.9932 * * *$ \\
\hline & Intercept & 0.029 & 0.004 & & & & & \\
\hline
\end{tabular}


Table 2. Precision, extraction yield and accuracy results $(\mathrm{n}=18)$

\begin{tabular}{|c|c|c|c|c|}
\hline $\begin{array}{l}\text { Spiked concentration / } \\
\left(\mathrm{ng} \mathrm{mL} \mathrm{mL}^{-1}\right)\end{array}$ & $\begin{array}{l}\text { Within-runR.S.D / } \\
(\%)\end{array}$ & $\begin{array}{c}\text { Between-runR.S.D / } \\
(\%)\end{array}$ & $\begin{array}{c}\text { Extraction yield / } \\
\qquad(\%)\end{array}$ & $\begin{array}{l}\text { Accuracy / } \\
(\%)\end{array}$ \\
\hline \multicolumn{5}{|l|}{$\overline{\mathrm{AT}}$} \\
\hline 15 & 5.7 & 6.9 & 72.3 & 101.8 \\
\hline 200 & 5.2 & 4.9 & 76.6 & 102.4 \\
\hline 400 & 3.5 & 3.1 & 75.1 & 101.8 \\
\hline \multicolumn{5}{|l|}{ NT } \\
\hline 15 & 4.9 & 5.6 & 70.2 & 98.5 \\
\hline 200 & 2.2 & 5.5 & 73.8 & 99.9 \\
\hline 400 & 2.9 & 3.8 & 75.3 & 102.5 \\
\hline \multicolumn{5}{|l|}{ NNT } \\
\hline 15 & 3.8 & 4.3 & 69.5 & 102.7 \\
\hline 200 & 3.1 & 4.9 & 69.5 & 100.9 \\
\hline 400 & 2.2 & 4.3 & 72.6 & 101.1 \\
\hline \multicolumn{5}{|l|}{ EHAT } \\
\hline 15 & 7.9 & 9.1 & 68.5 & 95.5 \\
\hline 200 & 7.2 & 8.8 & 68.4 & 98.3 \\
\hline 400 & 6.9 & 7.4 & 71.8 & 97.6 \\
\hline \multicolumn{5}{|l|}{ ZHAT } \\
\hline 15 & 8.8 & 11.3 & 83.2 & 95.8 \\
\hline 200 & 7.8 & 10.8 & 85.3 & 98.8 \\
\hline 400 & 6.2 & 8.2 & 82.6 & 96.9 \\
\hline \multicolumn{5}{|l|}{ EHNT } \\
\hline 15 & 10.5 & 12.1 & 37.3 & 96.4 \\
\hline 200 & 9.6 & 9.8 & 35.2 & 95.1 \\
\hline 400 & 9.7 & 9.7 & 39.7 & 96.3 \\
\hline \multicolumn{5}{|l|}{ ZHNT } \\
\hline 15 & 10.5 & 11.1 & 63.4 & 93.1 \\
\hline 200 & 10.3 & 9.8 & 67.4 & 96.8 \\
\hline 400 & 8.8 & 9.3 & 65.1 & 95.3 \\
\hline
\end{tabular}

Pharmacokinetic study.

Table 3. Metabolic ratios of AT demethylation 3 and 4 hours after a single oral dose and number of CYP2C19 active alleles

\begin{tabular}{llll}
\hline Volunteer & Number of CYP2C19 active alleles & {$[\mathrm{AT}] /[\mathrm{NT}](\mathrm{t}=3 \mathrm{~h})$} & {$[\mathrm{AT}] /[\mathrm{NT}](\mathrm{t}=4 \mathrm{~h})$} \\
\hline 1 & 2 & 2.44 & 2.00 \\
2 & 2 & 2.32 & 2.11 \\
3 & 2 & 1.64 & 2.29 \\
4 & 2 & 0.87 & 0.49 \\
5 & 0 & 19.24 & 12.52 \\
\hline
\end{tabular}

\section{Conclusions}

A HPLC-DAD for the simultaneous determination of AT, NT, NNT, EHAT, ZHAT, EHNT and ZHNT in small human plasma samples was described. The sample preparation is based on a two-step liquid-liquid extraction, without a solvent evaporation step. The method showed to be precise, accurate, specific and sensitive. Currently, this is the first report on the simultaneous quantification of AT, NT, NNT, EHAT, ZHAT, EHNT and ZHNT by HPLC-DAD. With the presented method, it was possible to calculate demethylation ratios after a single oral dose of $1 \mathrm{mg} \mathrm{kg}^{-1}$ of AT. The demethylation ratios for AT, as determined in this work, correlated with CYP2C19 genotype.

\section{Acknowledgments}

The authors are grateful to Lundbeck A/S (Copenhagen, Denmark) for the kind donation of reference samples of amitriptyline metabolites.

\section{References}

1. Anderson, I. M.; Depress. Anxiety 1998, 7, 11.

2. Barbui, C.; Hotopf, M.; Brit. J. Psychiat. 2001, 178, 129.

3. Breyer-Pfaff, U.; Pfandl, B.; Nill, K.; Nusser, E.; Monney, C.; Jonzier-Perey, M.; Baettig, D.; Baumann, P.; Clin. Pharmacol. Ther. 1992, 52, 350.

4. Ulrich, S.; Läuter, J.; Clin. Pharmacokinet. 2002, 41, 853. 
5. Preskorn, S. H.; Jerkovich, G. D.; J. Clin. Psychopharmacol. 1990, 10, 88

6. Venkatakrishnan, K.; Greenblatt, D. J.; von Moltke, L. L.; Schmider, J.; Harmatz, J. S.; Shader, R. I.; J. Clin. Pharmacol. 1998, 38, 112 .

7. Someya, T.; Shimoda, K.; Yasuda, S.; Morita, S.; Shibasaki, M.; Takahashi, S.; Eur. Neuropsychopharmacol. 1996, 6, 5.

8. Bertilsson, L.; Mellström, B.; Sjöqvist, F.; Life Sci. 1979, 25, 1285 .

9. Young, R. C.; Alexopoulos, G. S.; Shamoian, C. A.; Dhar, A. K.; Kutt, H.; Am. J. Psychiatry 1984, 141, 432.

10. Schneider, L. S.; Cooper, T. B.; Severson, J. A.; Zemplenyi, T.; Sloane, R. B.; J. Clin. Psychopharmacol. 1988, 8, 402.

11. Kirchheiner, J.; Brosen, K.; Dahl, M. L.; Gram, L. F.; Kasper, S.; Roots, I.; Sjöqvist, F.; Spina, E.; Brockmöller, J.; Acta Psychiatr. Scand. 2001, 104, 173.

12. Linden, R.; Ziulkoski, A. L.; Wingert, M.; Tonello, P.; Souto, A. A.; J. Braz. Chem. Soc. 2007, 18, 733.

13. de la Torre, R.; Ortuño, J.; Pascual, J. A.; González, S.; Ballesta, J.; Ther. Drug Monit. 1998, 20, 340.

14. Ulrico, S.; Isensee, T.; Pester, U.; J. Chromatogr., B 1996, 685, 81 .
15. Rasanen, I; Kontinen, I.; Nokua, J.; Ojanperä, I.; Vuori, E.; J. Chromatogr., B. 2003, 788, 243.

16. Härtter, S.; Hiemke, C. J.; J. Chromatogr. 1992, 578, 273.

17. Aymard, G.; Livi, P.; Pham, Y. T.; Diquet, B.; J. Chromatogr., B 1997, 700, 183 .

18. Frahnert, C.; Rao, M. L.; Grasmäder, K.; J. Chromatogr., B 2003, 794, 35.

19. Shah, V. P.; Midha, K. K.; Findlay, J. W. A.; Hill, H. M.; Hulse, J. D.; McGilveray, I. J.; McKay, G.; Miller, K. J.; Patnaik, R. N.; Powell, M. L.; Tonelli, A.; Viswanathan, C. T.; Yacobi, A.; Pharm. Res. 2000, 17, 1551.

20. Koski, A.; Sistonen, J.; Ojanperä, I.; Gergov, M.; Vuori, E.; Sajantila, A.; Forensic Sci. Int. 2006, 158, 177.

21. Pragst, F.; Herzler, M.; Herre, S.; Erxleben, B-T.; Rothe, M.; UV Spectra of Toxic Compounds, Verlag Dr. Dieter Helm: Heppenheim, 2001.

Received: April 2, 2007 Web Release Date: January 18, 2008 